Journal of Social Sciences (COES\&RJ-JSS)

ISSN (E): 2305-9249 ISSN (P): 2305-9494

Publisher: Centre of Excellence for Scientific \& Research Journalism, COES\&RJ LLC

Online Publication Date: $1^{\text {st }}$ April 2017

Online Issue: Volume 6, Number 2 Special, April 2017

https://doi.org/10.25255/jss.2017.6.2S.41.49

\title{
Computer Gamers Academic Performance in a Technological State College in Leyte, Philippines
}

Charles Lumbay, Christian Caben M. Larisma, Catalino L. Centillas Jr. Palompon Institute of Technology-Tabango-Campus,

Tabango, Leyte, Philippines

\begin{abstract}
:
This study was conducted in order to provide a point of reference information on the academic performance of computer gamer students of PIT-Tabango Campus. A total of 82 identified computer gamer students enrolled across all levels and across all the programs offered in Palompon Institute of Technology-Tabango Campus for the school year 20152016 were involved in the study. It uses secondary data in the form of grades reflected in the student prospectus; likewise, a questionnaire was utilized in satisfying the research inquiries. Based on the evaluative measures set by the school, results showed that an astonishing sixty (62) percent of the gamers were good performers in the academe. Twelve (12) percent were having an incomplete grade within the entire school year and seven (7) percent were dropped out of school during the second semester. Based on the findings of the study, it was revealed that being a computer gamer may affect the students' academic performance negatively if; a gamer plays too much (more than four hours a day), a gamer plays too often (more than four times a week), and a gamer plays until late night (10 to 12 midnight). Researchers recommended an in-depth study to include factors that were not embraced in the study, so as to help those computer gamers who have low performance in the academe.

Keywords:

Computer game, computer gaming, academic performance, on-line game, computer gamers

Citation:

Lumbay, Charles ; Larisma, Christian Caben M. ; Centillas Jr., Catalino L. (2017); Computer Gamers Academic Performance in a Technological State College in Leyte, Philippines; Journal of Social Sciences (COES\&RJ-JSS), Vol.6, No.2 Special, pp: 41-49; https://doi.org/10.25255/jss.2017.6.2S.41.49.
\end{abstract}




\section{Introduction}

In this modern world, games have been integrated in computers making thousands of various games available for those who are inclined to playing computer games. The advent of internet makes computer gaming more interactive and exciting, making the online gaming a reality. In fact, computer gaming transcended the norms of competitive games, today Defense of the Ancients 2 (DOTA 2) a very famous computer game have become a tool for a tournament inviting computer gamers from around the globe to compete for the prize pool amounting to no less than 2 million dollars for the champion.

In a published book by Marc Prensky (2006), he presents the case - profoundly countercultural but true nevertheless - that video and computer game playing, done appropriately, is actually very beneficial to today's "Digital Native" kids, who use them to prepare for life in the 21 st century. He further believes that kids are so attracted to these games because they are learning about important "future" things, from collaboration, to prudent risk taking, to strategy formulation and execution, to complex moral and ethical decisions. His arguments are supported by PhDs studying both violence and games in their totality, and by studies of gamers who have become successful corporate workers, entrepreneurs, leaders, doctors, lawyers, scientists and other professionals.

In a publication sponsored by IEEE Computer Society, Luis von Ahn (2006), it was mentioned that, through online games, people can collectively solve large-scale computational problems. Such games constitute a general mechanism for using brain power to solve open problems. In fact, designing such a game is much like designing an algorithm - it must be proven correct, its efficiency can be analyzed, a more efficient version can supersede a less efficient one, and so on. "Games with a purpose" have a vast range of applications in areas as diverse as security, computer vision, Internet accessibility, adult content filtering, and Internet search. Any game designed to address these and other problems must ensure that game play results in a correct solution and, at the same time, is enjoyable. People will play such games to be entertained, not to solve a problem - no matter how laudable the objective

In the study of Sarath A. Nonis \& Gail I. Hudson (2010), it was revealed that "the amount of time spent studying or at work had no direct influence on academic performance". We believe that the result of this study was in one way or another have something to contribute to our recent study. Thus, we included it in our review.

Another noteworthy study to review was that of Mark D. Griffiths\&Nigel Hunt (1998), their analysis on the study indicated that one in five adolescent was currently "dependent" upon computer games. Boys played significantly more regularly than girls and were more likely to be classified as "dependent." The earlier children began playing computer games it appeared the more likely they were to be playing at "dependent" levels.

M. D. Griffithset. al (2003), results of their study showed that adolescent gamers were significantly more likely to be male, significantly less likely to gender swap their characters, and significantly more likely to sacrifice their education or work. In relation to favorite aspects of game play, the biggest difference between the groups was that significantly more adolescents than adults claimed their favorite aspect of playing was 
violence. Results also showed that in general, the younger the player, the longer they spent each week playing.

"The results of an exploratory interview-based study of computer gaming within the "firstperson shooter" (FPS) game genre are reported. FPS gaming is a fast-paced form of goaldirected activity that takes place in complex, dynamic behavioral environments where players must quickly make sense of changes in their immediate situation and respond with appropriate actions. Gamers' perceptions and evaluations of various aspects of the FPS gaming situation are documented, including positive and negative aspects of game interfaces, map environments, weapons, computer-generated game characters (bots), multiplayer gaming on local area networks (LANs) or the internet, and single player gaming. The results provide insights into the structure of gamers' mental models of the FPS genre by identifying salient categories of their FPS gaming experience. It is proposed that aspects of FPS games most salient to gamers were those perceived to be most behaviorally relevant to goal attainment, and that the evaluation of various situational stimuli depended on the extent to which they were perceived either to support or to hinder goal attainment", Delwin Clarke \& Robert P. Duimering ().S.M. Grüsser, R. Thalemann, and M.D. Griffiths (2007), in their study, data showed that $11.9 \%$ of participants (840 gamers of 7069) fulfilled diagnostic criteria of addiction concerning their gaming behavior, while there is only weak evidence for the assumption that aggressive behavior is interrelated with excessive gaming in general. Results of this study contribute to the assumption that also playing games without monetary reward meets criteria of addiction. Hence, an addictive potential of gaming should be taken into consideration regarding prevention and intervention.

\section{Statement of the Problem}

In our school, we often hear students talking about their computer game experiences instead of the lectures in school. We also hear various comments from students expressing a deep concern for their classmates who were previously a good performer in school and becomes a poor performer, blaming computer games addiction as factor for the poor performance. In our observation and informal interviews from students we found out that some of our students were really engaging in computer games. One of the researcher had encountered the problem on students absence in class due to spending so much time in computer gaming. From the given instances, the researchers decided to team up and conduct a point of reference research to gather factual and scientific information regarding the academic performance of the students enrolled in our school who were engaged in playing computer games.

\section{Research Design of the Study}

This quantitative research aimed to gather information regarding the profile of the respondents, the computer games they usually played, their length of engagement in computer gaming, place where gamers usually play computer games, time of the day when they usually play computer games, the frequency of playing computer games in a week, and to determine their academic performance using the grades reflected in their individual prospectus covering two semesters in the school year 2015-2016. Data gathered were analyzed; conclusions and recommendations were made, and eventually baseline information regarding the academic performance of the computer gamers was produced. 


\section{Significance of the Study}

This study has importance to educators, school administrators, parents, and youths all over the country and internationally. For someone who wishes to monitor the effects of computer games among students this study will be of great aid for such. The study provided a new perspective on factors that may affect the academic performance of the students. Furthermore, since the results of this study compliments to the results of the previous study by S.M. Grüsser, R. Thalemann, and M.D. Griffiths (2007), educators and school administrators will find this study useful in considering prevention and intervention on the potential of computer gaming addiction.

\section{Method of Procedure}

The study utilized the descriptive survey method of research since the expected output is to provide baseline information regarding the academic performance of computer gamers. The researchers used purposive sampling in determining the respondents for the research which includes all of the 82 identified computer gamer students enrolled across all levels and across all the programs offered in Palompon Institute of Technology-Tabango Campus for the school year 2015-2016.

\section{Collection of Data}

This study made use of two data gathering techniques which was data mining in a form of grades from the student prospectus and the questionnaire. Respondents were informed personally and were guaranteed of utmost confidentiality as with regards to their identity for better data reliability and retrieval. Researchers also asked the permission of the school Registrar in gathering the individual prospectus of the students.

\section{Treatment of Data}

Data gathered were analyzed using percentage in order to identify proportions. Mean was used to determine the general weighted average grade of the gamers in each of the semesters during the school year 2015-2016.

\section{Findings}

In this study, it was revealed that 26.8 percent of the respondents were 18 year-old teens, 40.2 percent of the respondents usually played Dota 2, 26.8 percent of the respondents has been playing computer games from 13-18 months, 73.2 percent of the respondents usually played in an internet café, 34.1 percent of the respondents played computer games for 4 hours per day, 40.2 percent of the respondents usually played during the night (sometime form 6:00-12:00), 24.4 percent of the respondents played computer games 4 times a week, and an astonishing 62.1 percent of the respondents were good performers in the academe having an overall general weighted average ranging from 2.1-2.5.

Table 1. Age of respondents

\begin{tabular}{|c|c|c|}
\hline COMPUTER GAMERS' AGE & Frequency & Percentage \\
\hline 16 & 12 & 14.634146 \\
\hline 17 & 21 & 25.609756 \\
\hline 18 & 22 & 26.829268 \\
\hline 19 & 15 & 18.292683 \\
\hline 20 & 8 & 9.7560976 \\
\hline
\end{tabular}


Computer Gamers Academic Performance ...

\begin{tabular}{|c|c|c|}
\hline 21 & 2 & 2.4390244 \\
\hline 22 & 1 & 1.2195122 \\
\hline 23 & 1 & 1.2195122 \\
\hline & 82 & 100 \\
\hline
\end{tabular}

Table 1 showed the distribution of respondents by age, 22 of them were eighteen (18) years old and is closely followed in frequency by those aged seventeen (17) years old (21 respondents). There were 15 respondents at age 19, 12 respondents at age 16, and 8 respondents at age 20 . There were four students who were in their early twenties.

Table 2. Computer games usually played by respondents

\begin{tabular}{|l|l|l|}
\hline COMPUTER GAME & Frequency & Percentage \\
\hline Clash of Clans & 12 & 14.634146 \\
\hline Dota 2 & 33 & 40.243902 \\
\hline Counter Strike & 8 & 9.7560976 \\
\hline Heroes of New Earth & 5 & 6.097561 \\
\hline Dragon's Nest & 3 & 3.6585366 \\
\hline God's War & 2 & 2.4390244 \\
\hline Rakion & 1 & 1.2195122 \\
\hline War Commander & 3 & 3.6585366 \\
\hline Generals & 3 & 3.6585366 \\
\hline Plants vs Zombies & 4 & 4.8780488 \\
\hline NBA 2k12 & 6 & 7.3170732 \\
\hline Call of Duty & 2 & 2.4390244 \\
\hline & 82 & 100 \\
\hline
\end{tabular}

Table 2 showed that Dota 2 ranks first among the computer games that were usually played by the respondents, covering 40.2 percent (33 out of 82 gamers). Clash of Clans ranks second at 14.6 percent, Counter Strike at 9.8 percent, NBA $2 \mathrm{k} 12$ at 7.3 percent, Heroes of New Earth at 6.1 percent, Plants vs. Zombies at 4.9 percent, War Commander and Generals were tied at 3. 7 percent, Call of Duty and God's War were also tied at 2.4 percent, and Rakion occupies the last rank at 1.2 percent (1 out of 82 gamers).

Table 3. Respondent's length of engagement in playing computer games

\begin{tabular}{|l|c|l|}
\hline \multicolumn{1}{|c|}{ PLAYING ENGAGEMENT } & Frequency & Percentage \\
\hline 1-6 months & 6 & 7.3170732 \\
\hline 7-12 months & 9 & 10.97561 \\
\hline 13-18 months & 22 & 26.829268 \\
\hline 19-24 months & 20 & 24.390244 \\
\hline 25-30 months & 14 & 17.073171 \\
\hline 3 years & 3 & 3.6585366 \\
\hline 4 years & 4 & 4.8780488 \\
\hline
\end{tabular}


Journal of Social Sciences (COES\&RJ-JSS), 6(2) Special, pp. 41-49

\begin{tabular}{|l|c|c|}
\hline 5 years & 1 & 1.2195122 \\
\hline 6 years & 2 & 2.4390244 \\
\hline 7 years & 1 & 1.2195122 \\
\hline & 82 & 100 \\
\hline
\end{tabular}

Table 3 showed that 26.8 percent of the respondents had been playing computer games for 13-18 months, 24.4 percent had been playing for around 19-24 months, 17.1 percent played computer games from 25-30 months, 11 percent played computer games for around 7-12 months, 7.3 percent played computer games for 1-6 months, 4.9 percent had been playing computer games for 4 years, 3.6 percent played computer games for 3 years, 2.4 percent played computer games for 6 years, and tied at 1.2 percent were respondents who have been playing computer games for 5 and 7 years.

Table 4. Venue where respondents usually played computer games

\begin{tabular}{|l|c|l|}
\hline GAMING VENUE & Frequency & Percentage \\
\hline At home & 9 & 10.97561 \\
\hline In an internet café & 60 & 73.170732 \\
\hline On the cellular phone & 8 & 9.7560976 \\
\hline Friends' home & 3 & 3.6585366 \\
\hline Public library & 2 & 2.4390244 \\
\hline & 82 & 100 \\
\hline
\end{tabular}

As shown in table 4, most of the respondents played computer games in an internet café comprising 73.1 percent (60 out of 82). Other respondents played on the following places; at home (11 percent), friend's home (3.6 percent), and in a public library (2.4 percent).

Table 5. Typical number of playing hours of the respondents in a day

\begin{tabular}{|l|c|l|}
\hline \multicolumn{1}{|c|}{ PLAY TIME } & Frequency & \multicolumn{1}{c|}{ Percentage } \\
\hline Half (1/2) an hour & 2 & 2.4390244 \\
\hline One (1) hour & 4 & 4.8780488 \\
\hline Two (2) hours & 13 & 15.853659 \\
\hline Three (3) hours & 22 & 26.829268 \\
\hline Four (4) hours & 28 & 34.146341 \\
\hline Five (5) hours & 8 & 9.7560976 \\
\hline Six (6) hours & 5 & 6.097561 \\
\hline & 82 & 100 \\
\hline
\end{tabular}

As shown in table 5, 34.1 percent of the respondents usually played computer games four hours a day, 26.8 percent played 3 hours a day, 15.8 percent played 2 hours a day, 9.7 percent played 5 hours a day, 6 percent played six hours a day, 4.9 percent played 1 hour a day, and only 2.4 percent played half an hour a day. 
Computer Gamers Academic Performance ...

Figure 1. Time of the day when respondents usually play computer games

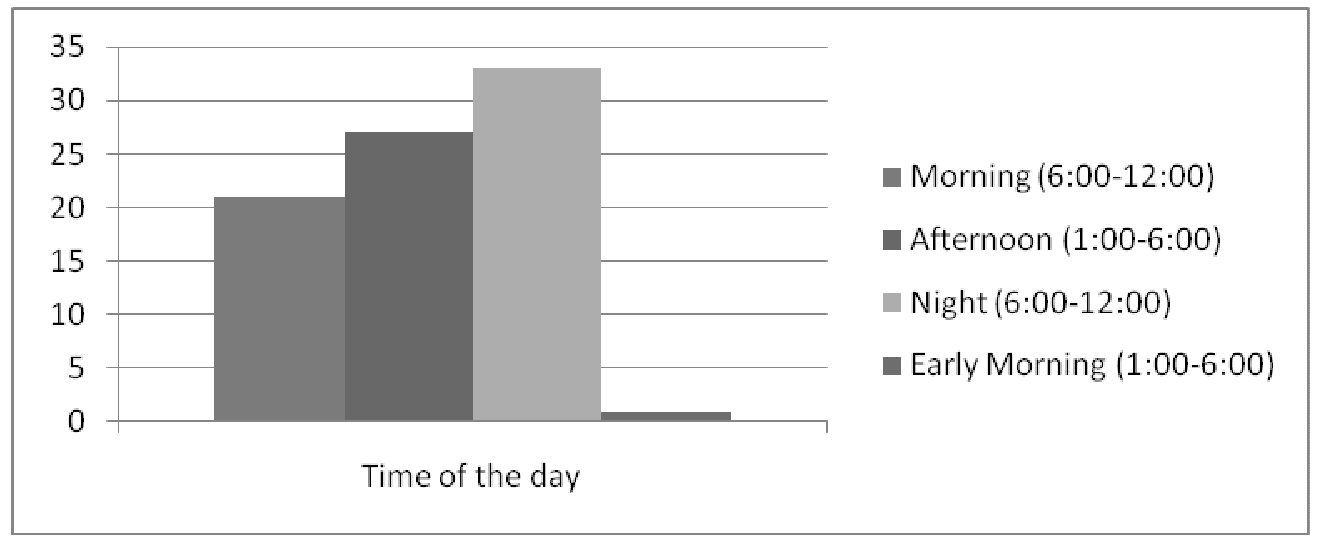

Figure 1 revealed the time of the day when the respondents usually played computer games. Thirty three (33) or 40.2 percent of the respondents played during the night (6:0012:00), 32.9 percent played during the afternoon (1:00-6:00), 25.6 percent played during the morning (6:00-12:00), and only one respondent played during the early morning (1:00-6:00).

Table 6. Number of time respondents played computer games in a week on daily basis

\begin{tabular}{|l|c|l|}
\hline PLAY PER WEEK & Frequency & Percentage \\
\hline Once (1 time) a week & 7 & 8.5365854 \\
\hline Twice (2 times) a week & 10 & 12.195122 \\
\hline Thrice (3 times) a week & 17 & 20.731707 \\
\hline Four (4) times a week & 20 & 24.390244 \\
\hline Five (5) times a week & 15 & 18.292683 \\
\hline Six (6) times a week & 8 & 9.7560976 \\
\hline Daily (7) times a week & 5 & 6.097561 \\
\hline & 82 & 100 \\
\hline
\end{tabular}

Table 6 showed that 24.4 percent of the respondents played computer games 4 times a week, 20.73 percent played 3 times a week, 18.3 percent played 5 times a week, 12.2 percent played twice a week, 9.8 percent played 6 times a week, 8.5 percent played once a week, and 6.1 percent played daily (7 days/week).

Figure 2. Distribution of respondents in terms of their academic performance 


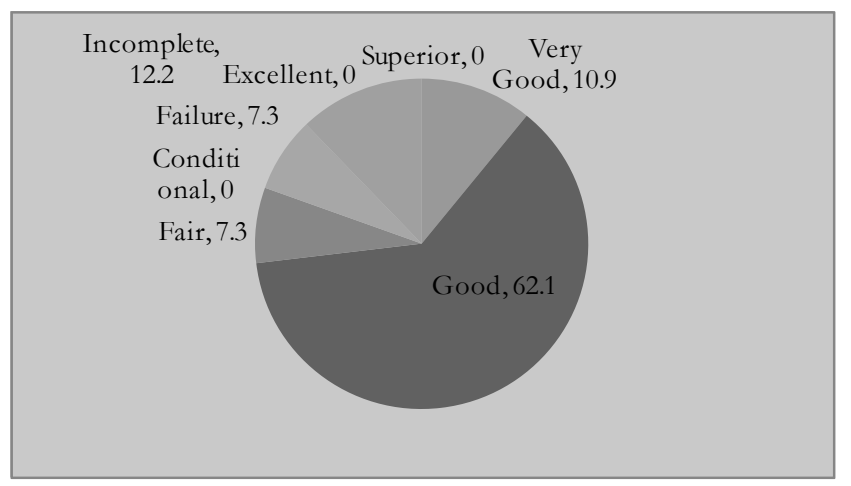

Figure 2 showed that an astonishing 62.1 percent of the respondents were good performers in the academe having an overall general weighted average ranging from 2.1-2.5, 12. 2 percent of the respondents had incomplete grades during the first semester or second semester or both, 10.9 percent has a very good academic performance with an average grade ranging from 1.6-2.0, tied at 7.3 percent were those who has fair performance with average grades ranging from 2.6-3.0 and those who were dropped during the second semester.

\section{Conclusion and Implication of the Study}

Based on the analysis of the data gathered, the researchers arrived at the following conclusion; majority of the computer gamers had already been playing computer games while they were still a junior high school student, this result strongly suggests that computer gaming exists not only among college students but also amongst high school students. Most of the gamers were good performers in the academe, this supports the belief of Prensky (2006), that video and computer game playing, done appropriately, is actually very beneficial to today's "Digital Native" kids, who use them to prepare for life in the 21 st century. The rest of the results compliments with the results of the previous studies cited in the review of related studies in this study (e.g. all of the gamers were males, most the gamers were adolescents).

Although this research was intended only to provide a point of reference information regarding the academic performance of the computer gamers in our school, considering the 12.2 percent of the gamers who had incomplete grades and the 7.3 percent who were dropped, though it is clear that there are several factors other than computer gaming which may have caused those failure in performance, based on the gathered data, the researchers could not help but formulate a weak general conclusion that being a computer gamer may affect the students' academic performance negatively if; a gamer plays too much (more than four hours a day), a gamer plays too often (more than four times a week), and a gamer plays until late night (10 to 12 midnight). The researchers recommend an in-depth study to include factors that were not embraced in this study, so as to provide intervention programs to help those computer gamers who have low performance in the academe. 


\section{References}

Ahn, L. v. (2006). Computer. 39 (6) 92-94. Print ISSN: 0018-9162

Clarke, D., \& Duimering, R. P. (2006). How computer gamers experience the game situation: A behavioral study. Computers in Entertainment (CIE) - Theoretical and Practical Computer Applications in Entertainment.Vol.4 (3) Article 6. Retrieved from http://dl.acm.org/

Griffiths, M. D., \& Hunt, N. (1998).Dependence on Computer Games by Adolescents. Retrieved from http://journals.sagepub.com/

Griffiths, M. D., Davies, M. N., \& Chappell, D. (2004). Online computer gaming: A comparison of adolescent and adult gamers. Journal of Adolescence, 27 (1) 87-96.

Grüsser, S. M., Thalemann, R., \& Griffiths M. D. (2007). Excessive computer game playing: Evidence for addiction or aggression?. Cyber Psychology \& Behavior, 10 (2) 290-292

Nonis, S. A., \& Hudson, G. I. (2010). Academic Performance of college students: Influence of time spent studying and working. Journal of Education for Business. 81 (3) 151-159. Retrieved from http://www.tandfonline.com/

Prensky, M. (2006). Don't bother me, Mom, I'm learning! How computer and video games are preparing your kids for $21^{\text {st }}$ century success and how you can help. St. Paul Paragon House. ISBN: 1-55778-858-8. 